\title{
Methylenetetrahydrofolate Reductase C677T Distribution among Cervical Cancer Patients at Dr. Hasan Sadikin General Hospital Bandung
}

\author{
Ani Melani Maskoen, ${ }^{1,2}$, Cynthia Kurniawan, ${ }^{2}$ Edhyana Sahiratmadja, ${ }^{2,3}$ Herman Susanto, ${ }^{2,4}$ \\ ${ }^{1}$ Department of Oral Biology, Faculty of Dentistry Universitas Padjadjaran, ${ }^{2}$ Centre of Oncology, Faculty of \\ Medicine Universitas Padjadjaran, ${ }^{3}$ Department of Biochemistry, Faculty of Medicine Universitas Padjadjaran, \\ ${ }^{4}$ Department of Obstetrics and Gynecology, Faculty of Medicine Universitas Padjadjaran Dr. Hasan Sadikin General \\ Hospital Bandung
}

\begin{abstract}
Cervical cancer is the second most common cancer among women in the world. Persistent infection with high risk human papillomavirus (HPV) is one of the necessary causes of cervical cancer development. However, host genetic factors may also play a role in cervical cancer carcinogenesis. Methylenetetrahydrofolate reductase enzyme, encoded by the MTHFR gene, regulates folate metabolism which is important for genetic expression and stability. Single nucleotide polymorphism (SNP) C677T in MTHFR gene may produce a thermo-labile enzyme, resulting in a reduced enzyme activity. The aim of this study was to explore the SNP C677T of MTHFR gene and the susceptibility to cervical cancer among cancer patients visiting Dr. Hasan Sadikin General Hospital, Bandung, Indonesia. This descriptive quantitative study involved cervical cancer patients recruited in 2010 and their control group. Genomic DNA was extracted from patients' blood. MTHFR C677T genotype was performed using BeadXpress Reader Illumina ${ }^{\circledR}$ and some samples were re-genotyped for confirmation using conventional PCRRFLP. The distribution of MTHFR C677T genotype in cervical cancer patients was $71.6 \%, 25.4 \%$, and $3 \%$, and $44 \%$, $36 \%$, and $20 \%$ in control group for CC, CT, and TT, respectively. This yielded a statistical significant difference of CC vs CT+TT (p 0.014 with OR 3.22 and CI 95\% 1.24 - 8.33). Taken together, this result indicates that T allele has a protective effect against cervical cancer development. Further studies to confirm this effect in bigger population is warranted. [MKB. 2016;48(4):216-21]
\end{abstract}

Key words: Cervical cancer, MTHFR C677T, polymorphism

\section{Distribusi C677T gen Methylenetetrahydrofolate Reductase pada Pasien Kanker Serviks di Rumah Sakit Dr. Hasan Sadikin Bandung}

\begin{abstract}
Abstrak
Kanker serviks menduduki peringkat kedua sebagai kanker yang paling sering ditemukan pada wanita di dunia. Infeksi persisten oleh human papillomavirus (HPV) tipe risiko tinggi merupakan salah satu penyebab utama kanker serviks. Selain itu, factor genetic juga turut berperan dalam proses perkembangan kanker serviks. Enzim methylenetetrahydrofolate reductase yang disandi oleh gen MTHFR berfungsi meregulasi metabolism folat. Polimorfisme C677T pada gen MTHFR dapat membuat produksi enzim menjadi termolabil sehingga terjadi penurunan aktivitas. Distribusi folat yang abnormal dapat mengganggu proses metilasi, sintesis, dan perbaikan DNA yang dikaitkan dengan perkembangan kanker serviks. Tujuan penelitian ini adalah mengetahui distribusi polimorfisme C677T gen MTHFR pada pasien kanker serviks di Rumah Sakit Umum Dr. Hasan Sadikin Bandung, Indonesia. Penelitian deskriptif kuantitatif ini melibatkan pasien kanker serviks yang diinklusi tahun 2010 dan sebagai control adalah wanita yang datang untuk pemeriksaan PAPsmear. DNA genomic diisolasi dari darah pasien dan dihibridisasi dengan menggunakan system BeadXpress Reader Illumina ${ }^{\circledR}$ untuk menentukan jenis genotipenya. Genotipe beberapa sampel dikonfirmasi dengan metode PCR-RFLP. Hasil distribusi polimorfisme C677T gen MTHFR dengan genotipe CC, CT, dan TT pada pasien kanker serviks adalah 71,6\%, 25,4\%, dan 3\% dan pada kontrol adalah 44\%,36\%, and 20\%. Hasil ini menunjukkan perbedaan yang signifikan antara pasien kanker serviks dan kontrolnya, dengan genotipe CC vs CT+TT menunjukkan nilai p=0,014 (OR 3.22 dan IK 95\% 1,24-8,33). Simpulan, alel T menunjukkan efek yang protektif pada perkembangan kanker serviks. Penelitian harus dilanjutkan untuk membuktikan efek protektif alel pada kanker serviks.[MKB. 2016;48(4):216-21]
\end{abstract}

Kata kunci: Kanker serviks, MTHFR C677T, polimorfisme

Correspondence: Dr. Ani Melani Maskoen, drg., M.Kes, Department of Oral Biology, Faculty of Dentistry Universitas Padjadjaran, Jl. Sekeloa Selatan No.1 Bandung, Jawa Barat 40132, mobile 08122350840, e-mail ani.maskoen@fkg.unpad.ac.id 


\section{Introduction}

Cervical cancer is the second most common cancer among women in the world, with the prevalence of 528.000 and 266.000 deaths as reported in 2012. ${ }^{1}$ Persistent infection with high risk human papillomavirus (HPV) is known as the predominant cause of cervical cancer. ${ }^{2}$ There are other risk factors influencing cervical cancer development, such as number of parity, ${ }^{3}$ oral contraceptives, ${ }^{4}$ cigarette smoking, ${ }^{5}$ and host genetic factors. ${ }^{6}$. As for host genetic factors, several genes are studied and may be responsible for cervical carcinogenesis, either in HPV persistence and disease progression. ${ }^{7}$

One of the genes that is involved in this disease is the MTHFR gene that encodes an enzyme, that is the methylenetetrahydrofolate reductase enzyme which catalyzes 5,10-methylenetetrahydrofolate to 5-methyltetrahydrofolate reaction. Hence, this enzyme determines folate coenzyme proportion for DNA synthesis or DNA methylation process as well as the abnormal DNA methylation process associated with carcinogenesis. ${ }^{8}$ Furthermore, the substrate 5,10 -methylenetetrahydrofolate is a precursor of deoxythimidine monophosphate (dTMP), known as coenzyme required for DNA synthesis and repair. Reduced dTMP level may thus increase the risk of mutation. ${ }^{8}$

There are single nucleotide polymorphisms (SNPs) in MTHFR gene among others C677T and A1298C. The most common SNP studied is C677T that substitutes cytosine to thymine at position of 677. This C677T SNP translates valine amino acid instead of alanine, and produces thermo-labile enzyme with reduced catalytic activity, thus this may influence cervical cancer risk. ${ }^{9}$ However, numerous studies of this gene in relation to susceptibility to cervical cancer have provided inconclusive results. The aim of this research was to explore the distribution of C677T polymorphism of MTHFR gene among cervical cancer patients at Dr. Hasan Sadikin General Hospital Bandung, Indonesia.

\section{Methods}

This descriptive study was part of the research under Center of Oncology Faculty of Medicine, Universitas Padjadjaran. Patients diagnosed with cervical cancer in 2010 were recruited from Dr. Hasan Sadikin General Hospital. Clinical data on age, parity, abortion status, and International Federation of Gynecology and Obstetrics (FIGO) staging were collected from Department of
Obstetrics and Gynecology. FIGO classification is clinical classification of cervical cancer which helps clinicians in determining diagnosis and treatment plan. ${ }^{10}$ Cervicalbiopsy was taken and sent to Department of Anatomic Pathology for histopathological diagnosis. The sample size for descriptive study with categorical variableswas calculated and the mininum sample size was set on 85. The controls for this study were unrelated female who came in the outpatient clinic for Pap smear screening and showed no abnormalities.

After informed consent for the genetic study, blood sample was taken into EDTA tube and further processed in the Molecular Biology Laboratory for genomic DNA extraction (QIAamp DNA Blood Mini Kit, Qiagen, Germany). SNP for MTHFR C677T was genotyped using protocol according to BeadsXpress Reader Illumina ${ }^{\circledR}$ as described earlier. ${ }^{11}$ In brief, three specific oligonucleotide primers (OPA) were prepared for each SNP, comprising two allele specific primers (ASPs) and one locus specific primer (LSP). The primers were then hybridized with the host genomic DNA, and PCR is then carried out, generating multiple amplicons with lables attached for all the different SNPs. Data on this system can be downloaded from http://support. illumina.com/array/array_instruments / beadxpress.ilmn).

Since the BeadsXpress Reader Illumina ${ }^{\circledR}$ method was new, a PCR-RFLP method was used to confirm the BeadsXpress genotype result. PCR condition for this study was as followed: initial denaturation $94^{\circ} \mathrm{C}$ for $8 \mathrm{~min}$, followed by 40 cycles consisting of denaturation phase $94^{\circ} \mathrm{C}$ for $1 \mathrm{~min}$, annealing $63^{\circ} \mathrm{C}$ for $1 \mathrm{~min}$, extension $72^{\circ} \mathrm{C}$ for $1 \mathrm{~min}$ and the final extension $72^{\circ} \mathrm{C}$ for $7 \mathrm{~min}$ then forever for $4^{\circ} \mathrm{C}$. The primer sequences pair used were as followed: 5'TGAAGGAGAAGGTGTCTGCGGGA3' and 5' AGGACGGTGCGTGAGAGTG3'. The PCR product yielded a 198 bp product.

The amplified PCR products were digested by Hinf I restriction enzyme at $37^{\circ} \mathrm{C}$ for 1 hour and the PCR-RFLP products was then visualized on $3 \%$ agarose gel stained with ethidium bromide. After HinfI enzyme digestion, undigested product showed a length of $198 \mathrm{bp}$ that was designated as the wild types or CC genotype. The TT genotype or homozygous polymorphic showed a PCRRFLP product of 175 and $23 \mathrm{bp}$ fragments, and as for CT genotype or heterozygous polymorphic, the PCR-RFLP product was digested into three fragments of 198,175 and 23 bp. The small 23 bp fragment was not shown on the gel, showing only 198 and 175 bp as depicted in Figure 1. 
Further data analyses only included patients with complete clinical and genetic data. Frequency of allele and genotypes were assessed using Hardy-Weinberg equilibrium and when the equilibrium was achieved ( $p>0.05)$, distribution of MTHFR C677T genotype was calculated and compared between patients and controlsusing chi-square test. The results were then presented in table. The research protocol was approved by the Ethics Committee Faculty of Medicine, Universitas Padjadjaran.

\section{Results}

In total, there were 100 women who visited the Obstetrics \& Gynecology Policlinic of Dr. Hasan Sadikin General Hospital during July to November 2010. After informed consent, 92 women were included in the study consisting of 67 women who were diagnosed as having cervical abnormality and 25 women who had no cervical abnormality and designated as control group. The median age was not significant different between patients (47 years old, range 35-70) compared to those who have no cervical abnormality (44 years old, range 26-67). The age of the patients group was significant different compared to controls ( $\mathrm{p}=0.02)$, and the most patients were in the age group of 41 to 60 years old. The clinical characteristics of patients with cervical cancer was shown in table 1 as compared to their controls. According to FIGO staging, most patients were diagnosed in stage II (40\%) and stage III (37\%) since the Dr. Hasan Sadikin General Hospital is a referral hospital in the province of West Java.

First, the Hardy-Weinberg equilibrium was assessed, resulting in the equilibrium of allele and genotype of both patients and control group ( $p>0.05$ ). Comparing the allele frequency of $\mathrm{C}$ and T in MTHFR C366T between cervical cancer patients and their control group has resulted in a significant different (p 0.01, OR $3.30 \mathrm{CI}$ 95\% 1.58-6.89). The distribution of MTHFR C677T genotype among cervical cancer patients showed that the most frequent genotype was the wild type of CC followed by genotype CT and TT for $71.6 \%, 25.4 \%$, and $3 \%$, respectively. In contrast with the control group, the distribution of the genotype was distributed in more equal percentage i.e. $44 \%, 36 \%$, and $20 \%$ for CC, CT, and TT, respectively as depicted in table 2 . Comparing the patients and controls for CC vs. CT+TT, there was a significant different p 0.014 (OR 3.22 and CI 95\% 1.24-8.33) indicating that $\mathrm{T}$ allele was protective for developing of cervical cancer. The distribution of MTHFR C677T genotype among the patients was shown in Figure 2. Furthermore, the distribution of

Table 1 Clinical Characteristics of Subjects

\begin{tabular}{lcc}
\hline & $\mathbf{n}$ & $\mathbf{0}$ \\
\hline Parity & & \\
Nulliparous & 1 & 1 \\
Primiparous (1) & 6 & 9 \\
Multiparous (2-4) & 40 & 60 \\
Grand Multiparous ( $\geq 5)$ & 20 & 30 \\
Abortion & & \\
$\quad 0$ & 38 & 57 \\
1 & 23 & 34 \\
2 & 2 & 3 \\
$\quad 3$ & 4 & 6 \\
FIGO staging & & \\
I & 13 & 19 \\
II & 27 & 40 \\
III & 25 & 37 \\
IV & 2 & 3 \\
(Mean \pm SD) (year) & & \\
\hline
\end{tabular}


Table 2 Distribution of MTHFR C677T Genotype among Cervical Cancer Patients in Dr. Hasan Sadikin General Hospital Period 2010-2011

\begin{tabular}{lcc}
\hline \multicolumn{1}{c}{ Genotype } & Frequency & $\mathbf{\%}$ \\
\hline CC & 48 & 71.6 \\
CT & 17 & 25.4 \\
TT & 2 & 3 \\
Total & 67 & 100 \\
\hline
\end{tabular}

MTHFR C677T genotype among the patients was then stratified according FIGO staging. Frequency of MTHFR C677T genotype stratified by FIGO staging showed no significant different across the FIGO groups as presented in Table 3.

\section{Discussion}

Our study has explored the role of the hostgenetic study MTHFR gene C667T and the susceptibility to cervical cancer. Initially, the change from cytosine to tymineat position 677 or C677T in MTHFR gene should decrease the activity of the methylenetetrahydrofolatereductaseenzyme, and thus the variations in folate pathway genes would increase the susceptibility to cancer, and also to several multifactorial disorders including neural tube defects, cardiovascular disease and recurrent pregnancy loss. ${ }^{12}$ However, the majority of cervical cancer patients in our study had CC genotype $(74.6 \%)$. This finding suggested that CC genotype may increase cervical cancer risk rather than the TT genotype. When compared to the genotype in control, the distribution of MTHFR C677T among cervical cancer patients in our study revealed that MTHFR C677T polymorphism was not associated with cervical cancer risk, but showed a result in an opposite direction i.e. protective effect and this result was similar to study from India. ${ }^{13}$ Interestingly, the distribution of C677T polymorphism in MTHFR gene in other part of India was reported with genotype CT as the most frequent genotype and the change in $\mathrm{C677T}$ was related to cervical cancer susceptibility. ${ }^{14}$ In other study, there is an evidence that there is different distribution of C677T genotype among different population, however, the C677T variants is not associated with cervical cancer susceptibility. ${ }^{15}$

Conflicting results regarding the effect of MTHFR C677T polymorphism in cervical cancer development may be related to different population and sample size, therefore, the association between the MTHFR polymorphisms and cervical risk has been thoroughly reviewed in different races. ${ }^{16}$ In this meta-analysis, data from Greek showed that MTHFR C677T did not associated cervical cancer development, instead, result in Caucasian population in the Netherland as well as in India showed that MTHFR C677T polymorphism might reduce the cervical cancer risk, indicating that a single nucleotide change from C677T in MTHFR gene may have protective effect in cervical cancer development. Furthermore, racial or ethnic differences in allele frequencies of single-nucleotide polymorphisms in the MTHFR gene and their influence on response to drugs is also evidenced in relation to other disease for example to methotrexate in rheumatoid arthritis. ${ }^{17}$

Although several meta-analysis studies which are performed to assess the association of C677T polymorphismin MTHFR gene and cervical cancer risk show no association, the effect of MTHFR C677T gene polymorphism in cervical cancer development is still uncertain. The C677T MTHFR may have two contradictive effects in cervical cancer development. Reduced activity of the enzyme encoded by the SNP was assumed to have protective effect due to increased level of the enzyme substrate, 5,10-methylenetetrahydrofolate, which is

Table 3 Distribution of MTHFR C677T Genotype Stratified by FIGO Staging

\begin{tabular}{lcccc}
\hline & \multicolumn{3}{c}{ Stage } & \\
\cline { 2 - 5 } & $\mathbf{I}$ & $\mathbf{I I}$ & $\mathbf{I I I}$ & IV \\
& $\mathbf{n}(\%)$ & $\mathbf{n}(\%)$ & $\mathbf{n}(\%)$ & $2(3)$ \\
\hline CC & $9(13)$ & $20(30)$ & $17(25)$ & 0 \\
CT & $4(6)$ & $7(1)$ & $6(9)$ & 0 \\
TT & 0 & 0 & $2(3)$ & $2(3)$ \\
Total & $13(19)$ & $27(40)$ & $25(37)$ & \\
\hline
\end{tabular}


Table 4 Distribution of MTHFR C677T Genotype Among Cervical Cancer Patients in Various Population

\begin{tabular}{lccc}
\hline \multicolumn{1}{c}{ Study Location } & $\begin{array}{c}\text { CC } \\
\mathbf{n}(\%)\end{array}$ & $\begin{array}{c}\text { CT } \\
\mathbf{n}(\%)\end{array}$ & $\begin{array}{c}\text { TT } \\
\mathbf{n ~ ( \% )}\end{array}$ \\
\hline Netherlands & $357(56)$ & $230(36)$ & $49(8)$ \\
India & $170(85)$ & $28(14)$ & $2(1)$ \\
Greece & $11(52)$ & $8(38)$ & $2(9)$ \\
Korea & $73(30)$ & $115(47)$ & $58(24)$ \\
Korea & $53(36)$ & $65(45)$ & $28(19)$ \\
Indonesia & $48(71)$ & $17(25)$ & $2(3)$ \\
\hline
\end{tabular}

important for DNA synthesis and repair. However, folate depletion negates this protective effect. Decreased level of enzyme product, 5-mehyltetrahydrofolate, due to the effect of polymorphism, is exarcerbated by reduced dietary intake of folate resulting in an aberrant DNA methylation. ${ }^{18}$ The hypermethylation of tumor suppresor genes, which represses its expression and favors tumor growth, is found in cervical cancer cells. Abnormal methylation process may also disrupt defense mechanism occured during integration process of virus gene to host genome. ${ }^{19} \mathrm{HPV}$ integrates its genetic material to host cells genome producing E6 and E7 protein. E6 protein inhibits p53 tumor suppresorgene, while E7 binds with pRB protein and activates transcription process. As a defense mechanism, epithelial cells have capability to make HPV genome as a target of DNAmethylation, thus blocking viral genetic transcription. In cervical cancer cells, no methylation in HPV genome would indicate impairment in defense mechanism against transformation of normal epithelial cells to cancer cells. ${ }^{20}$

The patients who came to the out patients clinic were not equally distributed between patients with cervical cancer and patients with normal PAP smear, therefore, sample size was one of the limitations of this study, especially the number of the control group. Next, the genotype data in some of the samples is not conclusive and failed to be analysed, and subjected to be excluded.

To conclude, the change from cytosine to tymineat nucleotide 677 in MTHFR gene is not necessarily leading to increase the susceptibility to cervical cancer. These finding should be replicated in larger studies and involved other polymorphism in MTHFR that is associated with cervical cancer risk i.e.A1298C polymorphism. The association between single nucleotide and susceptibility to cervical cancer warrants further investigations.

\section{References}

1. GLOBOCAN 2012. Cancer incidence and mortality worldwide [internet]. International Agency for Research on Cancer. [cited 02/03/2014]. Available from: http:// globocan.iarc.fr.

2. Lai CH, Huang HJ, Hsueh S, Chao A, Lin CT, Huang SL, et al. Human papillomavirus genotype in cervical cancer: a populationbased study. Int J Cancer. 2007;120(9):19992006.

3. International Collaboration of Epidemiological Studies of Cervical Cancer. Cervical carcinoma and reproductive factors: collaborative reanalysis of individual data on 16,563 women with cervical carcinoma and 33,542 women without cervical carcinoma from 25 epidemiological studies. Int J Cancer. 2006;119(5):1108-24.

4. Roura E, Travier N, Waterboer $\mathrm{T}$, de Sanjosé S, Bosch FX, Pawlita M, et al. The Influence of Hormonal factors on the risk of developing cervical cancer and pre-cancer: Results from the EPIC cohort. PLoS One. 2016;11(3):e0151427.

5. Collins S, Rollason TP, Young LS, Woodman CB. Cigarette smoking is an independent risk factor for cervical intraepithelial neoplasia in young women: a longitudinal study. Eur J Cancer. 2010;46(2):405-11.

6. Couto E, Hemminki K. Heritable and environmental components in cervical tumors. Int J Cancer. 2006;119(11):2699701.

7. Wang SS, Gonzalez P, Yu K, Porras C, Li $\mathrm{Q}$ Safaeian $\mathrm{M}$, et al. Common genetic variants and risk for HPV persistence and progression to cervical cancer. PLoS One. 
2010;5(1):e8667.

8. Botezatu A, Socolov D, Iancu IV, Huica I, Plesa A, Ungureanu C, et al. Methylenetetrahydrofolate reductase (MTHFR) polymorphisms and promoter methylation in cervical oncogenic lesions and cancer. J Cell Mol Med. 2013;17(4):5439.

9. Gruber BM. B-group vitamins: Chemoprevention?. Adv Clin Exp Med. 2016; 25(3):561-8.

10. Pecorelli S. Revised FIGO staging for carcinoma of the vulva, cervix, and endometrium. Int J Gynaecol Obstet. 2009; 105(2):103-4.

11. Panigoro R, Susanto H, Arrazeen MN, Tobing M, Maskoen AM, Sahiratmadja E. Exploring TLR2 gene polymorphisms in cervical cancer development. MKB. 2013;45(4):257-62

12. Levin BL, Varga E. MTHFR: Addressing Genetic Counseling Dilemmas Using Evidence-Based Literature. J Genet Couns. 2016;25(5):901-11.

13. Shekari M, Sobti RC, Kordi Tamandani DM, Suri V. Impact of methylenetetrahydrofolate reductase (MTHFR) codon (677) and methionine synthase (MS) codon (2756) on risk of cervical carcinogenesis in North Indian population. Arch Gynecol Obstet. 2008;278(6):517-24.

14. Nandan NK, Wajid S, Biswas S, Juneja SS, Rizvi M, Prakash R, et al. Allelic variations in 5, 10-methylenetetrahydrofolate reductase gene and susceptibility to cervical cancer in Indian women. Drug Metab Lett. 2008;2(1):18-22.

15. Rao GG, Kurien A, Gossett D, Griffith WF,
Coleman RL, Muller CY. A case-control study of methylenetetrahydrofolate reductase polymorphisms in cervical carcinogenesis. Gynecol Oncol. 2006;101(2):250-4.

16. Luo YL, Ye P, Zhang QH, Hu TT, Luo MH, Li MQ, et al. Methylenetetrahydrofolatereductase C677T polymorphism and susceptibility to cervical cancer and cervicalintraepithelial neoplasia: a meta-analysis. PLoS One. 2012; 7(9):e46272.

17. Hughes LB, Beasley TM, Patel H, Tiwari HK, Morgan SL, Baggott JE, et al. Racial or ethnic differences in allele frequencies of single-nucleotide polymorphisms in the methylenetetrahydrofolate reductase gene and their influence on response to methotrexate in rheumatoid arthritis. Ann Rheum Dis. 2006;65(9):1213-8.

18. Tong SY, Kim MK, Lee JK, Lee JM, Choi SW, Friso S, et al. Common polymorphisms in methylenetetrahydrofolate reductase gene are associated with risks of cervical intraepithelial neoplasia and cervical cancer in women with low serum folate and vitamin B12. Cancer Causes Control. 2011;22(1):6372.

19. Jiménez-Wences $H$, Peralta-Zaragoza $O$, Fernández-Tilapa G. Human papilloma virus, DNA methylation and microRNA expression in cervical cancer (Review). Oncol Rep. 2014;31(6):2467-76.

20. Li L, Xu C, Long J, Shen D, Zhou W, Zhou Q, etal. E6 and E7 gene silencing results in decreased methylation of tumor suppressor genes and induces phenotype transformation of human cervical carcinoma cell lines. Oncotarget. 2015;6(27):23930-43. 